\title{
Multi-Objective Optimization Method by Ratio Analysis in Determining Results in Decision Support Systems
}

\author{
${ }^{1}$ Wirda Fitriani, ${ }^{2}$ Andysah Putera Utama Siahaan \\ Faculty of Science and Technology, Universitas Pembangunan Panca Budi, Medan, Indonesia \\ Email: wirda@pancabudi.ac.id, andiesiahaan@gmail.com
}

\begin{abstract}
Decision support system in selecting a product aims to improve the company's performance in the selection of certain products. This system is excellent to apply to companies, especially in companies that produce goods. It is so that consumers will not experience disappointment in the selection of these items. Every company needs a decision support system that can help choose the best product results accurately based on predetermined criteria. It is to avoid fatal errors. Therefore a company is beneficial and makes decision making more comfortable, in the selection of goods. The method used in this study is Multi-Objective Optimization on the Base of Ratio Analysis (MOORA). Selection of product results will be more structured and achieved using the MOORA method. Companies in the selection of goods will be under the desired target and can also minimize errors.
\end{abstract}

Key Words: MOORA, DCS, prediction, sales.

\section{INTRODUCTION:}

The company produces products for resale to the public. The products produced are not always of good quality. Sometimes this product has a product defect [1]. The problem that often arises is that the product selection process is not natural and sometimes even trying to do. It must be solved by applying a method that can help the company to simplify the product selection process. It is done in order to overcome errors in the selection of goods so that the company has never experienced an error in selling the products. It takes a method that not only prioritizes subjectivity but uses data as a reference in improving the accuracy of product results so that the results of the election can be more effective and efficient. Decision support system method is a method that aims to simplify and provide alternatives to companies to get quality products and is expected to help solve the problems that exist in the company and consumers.

Each product has advantages and disadvantages so that the selection of goods must be implemented so that the results are satisfactory. The condition of the goods produced will always be different in each period. It depends on the quality of the company's planning before creating the product. Decision makers must always be done to get a quality product order. If done manually, this is not easy and inefficient because it requires time and can increase the evaluation costs and salary burden on employees who are assigned in the field. Besides, the decision response that must be taken cannot be made quickly and accurately [2]-[4].

The design of a decision support system aims to simplify and assist with product selection problems and is expected to make decisions appropriately [5]-[7]. If the supplier is not responsible and responds to the fulfillment of the request, it will cause problems, including the occurrence of fatal errors in the company in the supplier's selection. Therefore, companies that have many alternative suppliers must be active and careful in choosing a supplier. Product results are very influential on the smooth running of the company. Decision support systems are needed to keep the quality of goods in the company running smoothly so that the product is suitable for use by consumers. Therefore, the role of the MOORA method is significant in the company for the selection of goods to be used in the long run. Besides that, the smooth selection of these products will get optimal results because it has used the MOORA method. Computational product selection is expected to improve product quality and increase consumer purchasing power. This method is also expected to make it easier for a company admin to sort products.

\section{THEORIES:}

\subsection{Decision Support System}

Decision Support System is a system that is able to provide problem-solving abilities and communication skills for problems with semi-structured and unstructured conditions [8]. Decision Support System is a system that can provide problem-solving abilities and communication skills for problems with semi-structured and unstructured conditions. This 
system is used to assist decision making in semi-structured situations and unstructured situations, where no one knows for certain how decisions should be made [9].

DSS aims to provide information, guide, provide predictions and direct information users to make better decisions. This is a series of certain classes of computerized information systems that support business and organizational decision-making activities [10]. A properly designed DSS is an interactive software-based system intended to help decision makers compile useful information from raw data, documents, personal knowledge, and business models to identify and solve problems and make decisions [11]. Decision support systems are part of computerbased information systems including knowledge-based systems or knowledge management that are used to support decision making in an organization or company [12]. It can also be said as a computer system that processes data into information to make decisions from specific semi-structured problems [13].

\subsection{Multi-Objective Optimization on the basis of Ratio Analysis}

The MOORA method is the method introduced by Braurers and Zavadkas [14]. This relatively new method is used by Braurers in a multi-criteria decision making. The MOORA method has a level of flexibility and easy to understand in separating subjective from an evaluation process into decision weighting criteria with several decision-making attributes [15]. Several steps that need to be done to calculate the MOORA method will be explained below:

1. Make a Matrix of Responses

Raw data is the basic form of the matrix of responses with alternatives as lines and objectives, attributes/criteria, or indicators as columns [13]. Raw data usually still contains qualitative values so that it needs to be processed further into quantitative values to facilitate calculation before being used as matrix input data.The matrix of responses (Xij) shows the value of each alternative $i$ to the destination $j, i=1,2, \ldots, m ; m$ is the number of alternatives, $j=1,2, \ldots$, $\mathrm{n} ; \mathrm{n}$ is the number of goals.

2. Calculating Ratio

The first step of the ratio system method is to calculate the ratio. The ratio value is an alternative value $i$ to the attribute $\mathrm{j}$ divided by the denominator which represents all alternatives to the attribute $\mathrm{j}$. The best denominator is the square root of the sum of the squares of alternative values $i$ to $m$ against the attribute $j$.

3. Calculating Optimization Value

The next step of the ratio system method is to calculate the value of the optimization by adding up the value of the beneficial attributes $j$ to $g$ and then subtracting the value of the attribute cost (cost) $g+1$ to $n$ for each alternative $i$.

4. Reference Point Approach

This step is carried out when using the reference point approach method. If it is sufficient with the ratio system method, this step can be skipped and immediately proceed to the alternative ranking step. The ratio value obtained from the ratio system method is used as input data. The selection of reference point is done by selecting the largest ratio value if the benefit type and lowest ratio value if the cost type attribute of the $j$ attribute value for all alternatives $\mathrm{i}$ to $\mathrm{m}$. Furthermore, the distance between the ratio value in attribute $\mathrm{j}$ for each alternative $\mathrm{i}$ to the reference point measured using Tchebycheff Min-Max metric.

5. Alternatives Ranking

Alternative ranking for the system ratio method is done by sorting the optimization value of each alternative from the highest value to the lowest value. The alternative with the highest optimization value is the best alternative. Whereas the alternative rating for the reference point approach method is carried out in reverse, i.e. the value of the reference point approach is sorted from the lowest value to the highest value. The alternative with the lowest value is the best alternative.

\section{METHODOLOGY:}

This section contains raw data from product assessments and criteria. Product selection using the Multi-Objective Optimization method on the Base of Ratio Analysis involves specific parameters to perform the calculation process before getting the best alternative order.

Table 1. Initial Data

\begin{tabular}{|c|c|c|c|c|}
\hline Alternative & C1 & C2 & C3 & C4 \\
\hline A1 & 75 & 120 & 5 & 80 \\
\hline A2 & 88 & 212 & 4 & 74 \\
\hline A3 & 56 & 180 & 5 & 66 \\
\hline
\end{tabular}




\begin{tabular}{|l|l|l|l|l|} 
A4 & 81 & 130 & 3 & 94 \\
\hline A5 & 94 & 275 & 2 & 54 \\
\hline A6 & 71 & 315 & 5 & 43 \\
\hline A7 & 79 & 380 & 9 & 87 \\
\hline
\end{tabular}

Where:

$$
\begin{array}{ll}
\mathrm{A} 1-\mathrm{A} 7 & =\text { Alternatives } \\
\mathrm{C} 1, \mathrm{C} 3, \mathrm{C} 4 & =\text { Benefit } \\
\mathrm{C} 2 & =\text { Cost }
\end{array}
$$

Table 1 explains that there are seven alternatives available based on the data in the table. It is known that A1 to A7 is alternatives, $\mathrm{C} 1, \mathrm{C} 3, \mathrm{C} 4$ are benefits where the higher the value, the better the results. $\mathrm{C} 2$ is the cost where the lower the value, the better the result.

\section{RESULT AND DISCUSSION}

In this section, the MOORA method will be calculated to get good results from the highest to the lowest value. Following is the calculation of the method.

Calculation:

$$
\begin{aligned}
& C 1=\sqrt{\left(75^{2}+88^{2}+56^{2}+81^{2}+94^{2}+71^{2}+79^{2}\right)} \\
& C 1=\sqrt{43184} \\
& C 1=207.8076033 \\
& C 2=\sqrt{\left(120^{2}+212^{2}+180^{2}+130^{2}+275^{2}+315^{2}+380^{2}\right)} \\
& C 2=\sqrt{427894} \\
& C 2=654.136071 \\
& C 3=\sqrt{\left(5^{2}+4+5^{2}+3^{2}+2^{2}+5^{2}+9^{2}\right)} \\
& C 3=\sqrt{185} \\
& C 3=13.6014705 \\
& C 4=\sqrt{\left(80^{2}+74^{2}+66^{2}+94^{2}+54^{2}+43^{2}+87^{2}\right)} \\
& C 4=\sqrt{37402} \\
& C 4=193.395967
\end{aligned}
$$

After obtaining the divider value for each criterion, the next step is to normalize the matrix with each value. Normalization results can be seen in the following table.

Table 2. Normalization Data

\begin{tabular}{|c|c|c|c|c|}
\hline Alternative & C1 & C2 & C3 & C4 \\
\hline A1 & 0.36091076 & 0.18344807 & 0.36760731 & 0.41365909 \\
\hline A2 & 0.42346862 & 0.32409159 & 0.29408585 & 0.38263466 \\
\hline A3 & 0.26948003 & 0.27517211 & 0.36760731 & 0.34126875 \\
\hline A4 & 0.38978362 & 0.19873541 & 0.22056439 & 0.48604943 \\
\hline A5 & 0.45234149 & 0.42040183 & 0.14704292 & 0.27921989 \\
\hline A6 & 0.34166219 & 0.48155118 & 0.36760731 & 0.22234176 \\
\hline A7 & 0.38015933 & 0.58091889 & 0.66169316 & 0.44985426 \\
\hline
\end{tabular}

Normalization results will be adjusted according to the weights for each criterion. The weight for $\mathrm{C} 1$ is $0.3, \mathrm{C} 2$ is $0.2, \mathrm{C} 3$ is 0.2 and $\mathrm{C} 4$ is 0.3 . Weighting results can be seen in the following table. 
Table 3. Weighted Data

\begin{tabular}{|c|c|c|c|c|}
\hline Alternative & C1 & C2 & C3 & \multicolumn{1}{c|}{ C4 } \\
\hline A1 & 0.10827323 & 0.03668961 & 0.07352146 & 0.12409773 \\
\hline A2 & 0.12704059 & 0.06481832 & 0.05881717 & 0.1147904 \\
\hline A3 & 0.08084401 & 0.05503442 & 0.07352146 & 0.10238063 \\
\hline A4 & 0.11693509 & 0.03974708 & 0.04411288 & 0.14581483 \\
\hline A5 & 0.13570245 & 0.08408037 & 0.02940858 & 0.08376597 \\
\hline A6 & 0.10249866 & 0.09631024 & 0.07352146 & 0.06670253 \\
\hline A7 & 0.1140478 & 0.11618378 & 0.13233863 & 0.13495628 \\
\hline
\end{tabular}

Table 4. Max Min Data

\begin{tabular}{|c|l|c|l|}
\hline Alternative & \multicolumn{1}{|c|}{ Maximum } & Minimum & \multicolumn{1}{|c|}{ Y (Max - Min) } \\
\hline A1 & 0.30589242 & 0.03668961 & 0.2692028 \\
\hline A2 & 0.30064816 & 0.06481832 & 0.23582984 \\
\hline A3 & 0.2567461 & 0.05503442 & 0.20171168 \\
\hline A4 & 0.30686279 & 0.03974708 & 0.26711571 \\
\hline A5 & 0.248877 & 0.08408037 & 0.16479663 \\
\hline A6 & 0.24272265 & 0.09631024 & 0.14641241 \\
\hline A7 & 0.38134271 & 0.11618378 & 0.26515893 \\
\hline
\end{tabular}

Table 4 is the result of the calculation of Max Min based on the previous table. MOORA calculation results produce a different sequence with the initial data. A1 is at the highest position with a value of 0.2692028 while A6 is the last rank with a value of 0.14641241 . Table 5 is the result of the seventh alternative sequence after calculation.

Table 5. Rankin result

\begin{tabular}{|c|c|c|}
\hline Alternative & Y & Rank \\
\hline A1 & 0.2692028 & 1 \\
\hline A4 & 0.26711571 & 2 \\
\hline A7 & 0.26515893 & 3 \\
\hline A2 & 0.23582984 & 4 \\
\hline A3 & 0.20171168 & 5 \\
\hline A5 & 0.16479663 & 6 \\
\hline A6 & 0.14641241 & 7 \\
\hline
\end{tabular}

\section{CONCLUSION:}

The MOORA method can be used to produce product selection recommendations based on several decision-making criteria. The recommendations generated by this method are products that have been sorted from highest to lowest. Better quality products do not always have a higher cost than benefits. This method can determine good alternatives for several alternative options provided.

\section{REFERENCES:}

1. H. A. Hasibuan, R. B. Purba, dan A. P. U. Siahaan, "Productivity Assessment (Performance, Motivation, and Job Training) using Profile Matching," Int. J. Econ. Manag. Stud., vol. 3, no. 6, hal. 73-77, 2016.

2. Mesran, K. Tampubolon, R. D. Sianturi, F. T. Waruwu, dan A. P. U. Siahaan, "Determination of Education Scholarship Recipients Using Preference Selection Index," Int. J. Sci. Res. Sci. Technol., vol. 3, no. 6, hal. 230 234, 2017. 
3. Mesran, R. K. Hondro, M. Syahrizal, A. P. U. Siahaan, R. Rahim, dan Suginam, "Student Admission Assessment using Multi-Objective Optimization on the Basis of Ratio Analysis (MOORA)," J. Online Jar. COT POLIPD, vol. 10, hal. 1-6, 2017.

4. D. Siregar et al., "Multi-Attribute Decision Making with VIKOR Method for Any Purpose Decision," J. Phys. Conf. Ser., vol. 1019, hal. 012034, Jun 2018.

5. M. D. T. P. Nasution et al., "Decision Support Rating System with Analytical Hierarchy Process Method," Int. J. Eng. Technol., vol. 7, no. 2.3, hal. 105-108, 2018.

6. I. Sumartono, D. Arisandi, A. P. U. Siahaan, dan Mesran, "Expert System of Catfish Disease Determinants Using Certainty Factor Method," Int. J. Recent Trends Eng. Res., vol. 3, no. 8, hal. 202-209, Agu 2017.

7. R. F. Wijaya, Y. M. Tondang, dan A. P. U. Siahaan, "Take Off and Landing Prediction using Fuzzy Logic," Int. J. Recent Trends Eng. Res., vol. 2, no. 12, hal. 127-134, 2016.

8. J. CAMERON FISHER, dan S. ALTMAN, "DECISION SUPPORT SYSTEMS IN ACADEMIC ADMINISTRATION," J. Educ. Adm., vol. 26, no. 1, hal. 97-113, Jan 1988.

9. E. Turban, J. E. Aronson, dan T. Liang, Decision Support Sistems and Intelligent Systems. Yogyakarta: Andi, 2005.

10. B. G. Raggad, "Effects of information structure and problem solving on decision-support system choice," Ind. Manag. Data Syst., vol. 96, no. 1, hal. 21-27, Feb 1996.

11. H. C. W. Lau, A. Ning, W. H. Ip, dan K. L. Choy, "A decision support system to facilitate resources allocation: an OLAP-based neural network approach," J. Manuf. Technol. Manag., vol. 15, no. 8, hal. 771-778, Des 2004.

12. H. M. Ritonga, A. P. U. Siahaan, dan Suginam, "Marketing Strategy through Markov Optimization to Predict Sales on Specific Periods," Int. J. Innov. Res. Multidiscip. F., vol. 3, no. 8, hal. 184-190, 2017.

13. N. Mayasari, "Comparison of Support Vector Machine and Decision Tree in Predicting On-Time Graduation (Case Study: Universitas Pembangunan Panca Budi)," Int. J. Recent Trends Eng. Res., vol. 2, no. 12, hal. 140$151,2016$.

14. L. Pérez-Domínguez, A. Alvarado-Iniesta, I. Rodríguez-Borbón, dan O. Vergara-Villegas, "Intuitionistic Fuzzy MOORA for Supplier Selection," DYNA, vol. 82, no. 191, hal. 34-41, Jun 2015.

15. A. Kumar Sahu, N. Kumar Sahu, dan A. Kumar Sahu, "Appraisal of CNC machine tool by integrated MULTIMOORA-IVGN circumferences,” Grey Syst. Theory Appl., vol. 4, no. 1, hal. 104-123, Jan 2014. 